New biotech patents continue to issue. Biogen was granted a U.S. patent, similar to the one it already holds in Europe, for production of recombinant alpha interferons. Also, Cetus Corp. (Emeryville, CA) received a U.S. composition-of-matter patent for microbially produced disulfidecontaining proteins, including interleukin-2 and beta interferon.

In product news, Cetus introduced two monoclonal antibody-based tests for prostate cancer, the Cetus Epichrome $^{\mathrm{TM}}$ PAP and Cetus Epichrome ${ }^{\mathrm{TM}}$ PA tests. Integrated Genetics (Framingham, MA) is now marketing its first product, a DNA probe-based test kit to detect Salmonella in food.

On the scientific front, Cetus announced that it has become the first to clone and express biologically active colony stimulating factor-1 (CSF1), which could be useful in treating infectious diseases and cancer. Genentech (South San Fancisco, CA) reported discovering a hormone that inhibits the release of the hormone prolactin, which is related to fertility.

\section{Recent agreements:}

- Monsanto (St. Louis, MO) announced that it plans to acquire G.D. Searle (Skokie, IL) for $\$ 2.7$ billion, a move that may help Monsanto commercialize its biotechnology products.

- Corning Glass Works (Corning, NY) and CIBA-Geigy Ltd. (Basel, Switzerland) formed a joint venture called CIBA Corning Diagnostics Corp. to develop medical diagnostic products.

- CIBA-Geigy also agreed to pay Genentech about $\$ 42$ million for exclusive rights to certain of Genentech's animal health care products, including animal interferons.

- Stryker Corp. (Kalamazoo, MI) and Creative Biomolecules (Hopkinton, MA) reached a long-term agreement covering research, development, and supply of human osteogenic protein for repair of bone defects and as a bone graft substitute.

- Triton Biosciences (Alameda, CA), a division of Shell Oil, and Technicon (Tarrytown, NY), a subsidiary of Revlon, will develop and market an automatic immunoassay instrument and associated clinical laboratory assays.

- Nova Pharmaceutical Corp. (Baltimore, MD) obtained rights to pharmaceutical applications for over 1,000 chemicals from the Institut de
Recherche Chimique Appliquee.

- Cambridge BioScience Corp. (Hopkinton, MA) will manufacture and supply monoclonal antibodybased feline leukemia virus (FeLV) diagnostic kits to Norden Laboratories (Lincoln, NE) for sale to the veterinary community.

- Technogenetics (New York, NY) has received certain international marketing rights to the AIDS bloodscreening test kit developed and manufactured by Cellular Products (Buffalo, NY).

- Kraft (Glenview, IL) plans to market VegiSnax, the ready-to-eat vegetables developed by DNA Plant Technology (Cinnaminson, NJ).

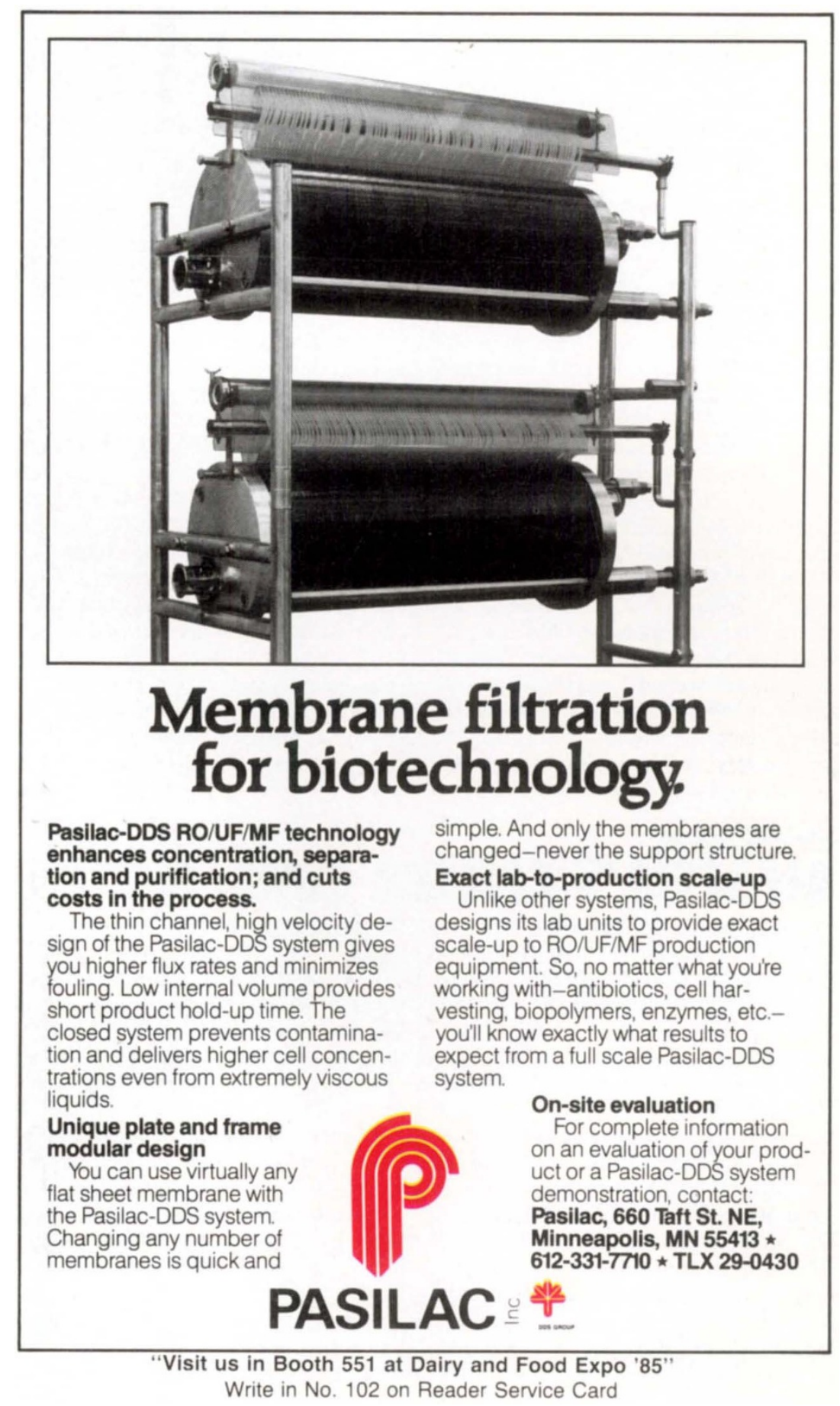

